\title{
POLA HUBUNGAN SOSIAL ANAK DI KELAS BERDASARKAN SOSIOMETRI
}

\author{
Hendri Leo Pradana \\ Universitas Kristen Satya Wacana \\ Email: hendrileopradana10@gmail.com
}

\begin{abstract}
ABSTRAK
Penelitian ini bertujuan untuk mengkaji pola hubungan sosial anak di kelas berdasarkan sosiometri. Metode penelitian yang digunakan adalah penelitian deskriptif kualitatif. Jenis penelitian yang digunakan dalam penelitian ini adalah penelitian studi kepustakaan (library research) untuk mengkaji pola-pola hubungan sosial anak di kelas berdasarkan penggambaran sosiogram yang diukur menggunakan sosiometri. Teknik pengumpulan data dalam penelitian ini dengan melakukan identifikasi wacana dari buku-buku atau jurnal-jurnal ilmiah diinternet yang memiliki hubungan dengan judul penulisan untuk mencari hal-hal terkait kajian pola hubungan sosial anak di kelas berdasarkan sosiometri. Berdasarkan hasil dan pembahasan, maka dapat ditarik kesimpulan bahwa ada tiga pola hubungan sosial anak yang akan muncul di kelas, yaitu bintang (star), terisolir, dan klik (geng).
\end{abstract}

Kata Kunci: Hubungan Sosial, Pola Hubungan Sosial, Sosiometri

\section{CHILDREN'S SOCIAL RELATIONSHIP PATTERN IN CLASS BASED ON SOCIOMETRY}

\begin{abstract}
This study aims to examine the patterns of social relations of children in the classroom based on sociometry. The research method used was descriptive qualitative research. This type of research used in this study is the study of library research (library research) to examine patterns of social relations of children in the classroom based on the depiction of sociograms measured using sociometry. Data collection techniques in this study were to identify discourses from internet books or scientific journals that have a relationship with the title of the writing to look for things related to the study of children's social relations patterns in the classroom based on sociometry. Based on the results and discussion, it can be concluded that there are three patterns of social relations of children that will appear in class, namely the star (star), isolated, and click (gang).
\end{abstract}

Keywords: Social Relations, Social Relations Patterns, Sociometry 


\section{PENDAHULUAN}

Pendidikan dalam masyarakat saat ini telah menjadi kebutuhan pokok selain kebutuhan pangan dan sandang. Tidak terkecuali masyarakat pada tingkat sosial dan ekonomi rendah, menengah, atau tinggi. pendidikan yang berlaku dalam lingkungan masyarakat dibagi menjadi tiga bentuk, diantaranya pendidikan formal, informal, dan nonformal. Pendidikan dalam tingkat paling sederhana sampai dengan kompleks merupakan bagian dari struktur kehidupan masyarakat. Pendidikan merupakan salah satu alat yang digunakan untuk kelangsungan hidup masyarakat itu sendiri melalui norma-norma yang ada dalam lingkungannya. Dengan kata lain, tanpa pendidikan maka masyarakat tidak dapat melanjutkan keberlangsungan hidupnya, karena melalui proses pendidikan akan mengikat masyarakat sesuai dengan norma yang berlaku.

Menurut Undang-Undang Nomor 20 Tahun 2003 tentang sistem pendidikan nasional, pendidikan adalah usaha sadar dan terencana untuk mewujudkan suasana belajar dan proses pembelajaran agar peserta didik secara aktif mengembangkan potensi dirinya untuk memiliki kekuatan spiritual keagamaan, pengendalian diri, kepribadian, kecerdasan, akhlak mulia, serta keterampilan yang diperlukan dirinya, masyarakat, bangsa dan negara. Kemudian seperti yang disebutkan diatas bahwa pendidikan dibagi menjadi tiga bentuk, formal, informal, dan nonformal. Pendidikan formal merupakan jalur pendidikan terstruktur dan berjenjang yang terdiri atas pendidikan dasar, pendidikan menengah, dan pendidikan tinggi. Pendidikan nonformal merupakan jalur pendidikan di luar pendidikan formal yang dapat dilaksanakan secara terstruktur dan berjenjang. Pendidikan informal merupakan jalur pendidikan keluarga dan lingkungan (dikutip dari https://komisiinformasi.go.id/?p=1638)

Dari pengertian pendidikan diatas, usaha sadar yang dimaksud adalah proses interaksi antara pendidik dengan peserta didik dalam menciptakan suasana belajar. Peserta didik menjadi subyek yang disasar untuk dapat menambah pengetahuan dan ilmu untuk bekal dalam kehidupannya nanti. Pendidikan untuk peserta didik dimaksudkan agar mendapatkan ilmu dan pengetahuan semata-mata untuk 
memberikan bekal untuk kehidupannya kelak saat sudah bermasayarakat, bukan untuk mendapatkan nilai berupa angka yang merupakan formalitas yang berlaku di sekolah. Peserta didik diharapkan mampu memperoleh nilai-nilai yang berlaku dalam lingkungan masyarakat seperti halnya, gotong royong, kejujuran, kerja keras, toleransi, sosialisasi, dan yang lain sebagainya.

Dalam proses pendidikan, nilai-nilai kehidupan yang diajarkan kepada siswa dimaksudkan agar siswa bukan hanya dapat mengembangkan kemampuan kognitifnya, melainkan juga aspek lainnya sesuai dengan yang dituju oleh pendidikan nasional melalui kurikulum. Selain itu, siswa harus mampu menerapkan nilai-nilai yang berlaku dimasyarakat yaitu sosialisasi. Secara tidak langsung nilai sosialisasi merupakan bagian dari aspek afektif. Sosialisasi merupakan aspek yang sangat kompleks dalam mewujudkan nilai-nilai yang lainnya. Sosialisasi dapat diterapkan oleh peserta didik dalam membangun hubungan dengan teman sebaya dan warga sekolah. Dengan menjalin hubungan sosial, maka peserta didik cenderung untuk dapat memperoleh ide dari teman sebaya atau warga sekolah dalam menyelesaikan suatu masalah yang dia sedang hadapi.

Menurut Sunatro dan B. Agung Hartomo dalam Buku Perkembangan Peserta Didik yang dikutip dari jurnal ilmiah Nur Hasanah, hubungan sosial diartikan sebagai hubungan antarmanusia yang saling membutuhkan. Dalam pengertian tersebut hubungan sosial diartikan sebagai hubungan timbal balik yang terjadi diantara siswa seperti pertemanan. Suasana hubungan sosial yang berlangsung dalam lingkup sekolah cenderung dinamis. Hubungan sosial antar peserta didik akan berbeda karakteristiknya karena pada dasarnya setiap peserta didik sekelas atau beda kelas memiliki karakter individu yang berbeda-beda. Di kelas dapat dilihat bahwa peserta didik cenderung ada yang aktif dalam belajar dan ada yang aktif dalam bermain. Hal ini memungkinkan munculnya pola hubungan segitiga (triangle) karena peserta didik akan berkumpul dengan teman yang memiliki aktifitas yang sama. Namun akan muncul kemungkinan lainnya, bahwa peserta didik dapat menyatu 
dengan kelompok lainnya yang memiliki kesenangan aktifitas yang sama. Hal ini karena dipengaruhi oleh keterbukaan peserta didik terhadap obyek atau subyek.

Peserta didik yang suka bermain dalam kelas cenderung kurang bisa menjalin hubungan dengan kelompok yang suka belajar di kelas kecuali untuk bermain. Peserta didik akan lebih menyendiri atau berkumpul dengan teman yang memiliki kesenangan untuk bermain. Untuk siswa yang suka belajar untuk mengerjakan sesuatu apapun hasilnya, biasanya akan menjadi pusat perhatian temannya untuk diajak berinteraksi. Pola hubungan ini memang tidak pasti karena disebabkan oleh kecenderungan suasana saat pembelajaran. Apabila keberagaman pola hubungan sosial ini dapat dikelola dengan baik oleh guru kelas maka akan menghasilkan dampak yang positif dalam kaitannya dengan motivasi mereka dalam belajar. Pola hubungan om yang dihasilkan siswa ini dapat diukur dengan menggunakan teknik sosiometri.

\section{LANDASAN TEORI}

Sosiometri (sociometry) didefinisikan sebagai teknik untuk memetakan relasi daya Tarik dan daya tolak anggota dalam suatu kelompok, Anwar Sutoyo (2012). Sedangkan menurut Gantina Komalasari dkk (2011), sosiometri merupakan metode pengumpulan data tentang pola dan struktur hubungan antar individu-individu dalam suatu kelompok. Dengan demikian, sosiometri merupakan suatu cara untuk mengukur derajat hubungan antar individu/orang/manusia. Sosiometri digunakan sebagai penilaian perilaku seseorang dalam suatu kelompok tertentu. Sosiometri mengukur kualitas hubungan seorang individu dengan individu yang lainnya, kelompok dengan kelompok lainnya, individu dengan kelompok lainya dan begitu sebaliknya, yang penggambarannya disebut sebagai sosiogram.

Menurut Anwar Sutoyo (2012), sosiogram merupakan hasil ungkapan relasi antar anggota kelompok. Menurutnya, kemungkinan pola atau bentuk hubungan yang muncul dari sosiogram adalah pola hubungan segitiga (triangle), bintang (stars), jala 
atau net, dan rantai (chain). Keberagaman pola hubungan yang muncul ini berbanding lurus dengan keberagaman karakteristik individu di dalam suatu kelompok.

Melalui keberagaman pola hubungan peserta didik, maka guru dapat mengoptimalkan suasana pembelajaran untuk menciptakan pola hubungan yang baik dan merata dalam suatu kelas, sehingga akan berdampak positif bagi bekal peserta didik dikehidupannya kelak. Selain itu, guru juga dapat meberikan motivasi belajar bagi anak melalui pengoptimalan proses pembelajaran yang dilaksanakan di dalam kelas.

\section{HASIL PENELITIAN DAN PEMBAHASAN}

\section{Hubungan Sosial Anak}

Menurut Sunatro dan B. Agung Hartomo dalam Buku Perkembangan Peserta Didik yang dikutip dari jurnal ilmiah Nur Hasanah (2012) hubungan sosial diartikan sebagai hubungan antarmanusia yang saling membutuhkan. Dalam pengertian tersebut hubungan sosial diartikan sebagai hubungan timbal balik yang terjadi diantara siswa seperti pertemanan. Nur Hasanah (2012) mengartikan hubungan sosial adalah cara seseorang dalam menyikapi atas apa yang telah ia katakan atau lakukan sehingga orang tersebut dapat menyesuaikan diri pada lingkungan di mana ia berperilaku. Sedangkan menurut Emmi Khalilah (2017), Secara umum, “hubungan”, merupakan satu kata yang pengertiannya disamakan dengan kata "interaksi" yaitu pengaruh timbal balik atau saling mempengaruhi satu sama lain. Sedangkan yang yang dimaksud dengan sosial adalah segala sesuatu mengenai masyarakat; atau peduli terhadap kepentingan umum.

Dwi Kurnia (2011) mendefinisikan hubungan sosial sebagai hubungan yang terjadi ketika seseorang berinteraksi atau melakukan hubungan serta bersosialisasi dengan alam, manusia, lingkungan di sekitarnya mulai dari lingkup terkecil yaitu, keluarga sendiri, teman, sekolah, tetangga, dll. Sedangkan menurut Abu Ahmadi (2004) dalam Neltari (2018) hubungan sosial dapat diartikan sebagai cara- cara individu bereaksi terhadap orang- orang disekitarnya dan bagaimana pengaruh 
hubungan itu terhadap dirinya. Hartomo dan Arnicun Azis (1990) dalam Putri Andayani (2013) hubungan sosial adalah proses yang membantu individu melalui belajar dan penyesuaian diri, bagaimana bertindak dan berpikir ia dapat berperan dan berfungsi baik sebagai individu maupun sebagai anggota masyarakat.

Dengan demikian, hubungan sosial merupakan suatu proses interaksi yang dilakukan oleh manusia sebagai usaha menyesuaikan dirinya dengan lingkungan dia hidup untuk dapat mengubah perilaku individu. Sebagai individu, manusia juga merupakan anggota masyarakat, yang mana dia akan berperan dalam kehidupan bermasyarakat di lingkungannya. Oleh karena itu, hubungan sosial anak merupakan suatu proses interaksi yang dilakukan oleh anak sebagai usaha menyesuaikan dirinya dengan lingkungan dia hidup untuk dapat mengubah perilaku individu, yang mana dia akan lebih banyak berinteraksi dengan anak seusianya yang lain.

\section{Sosiometri}

Dalam Rumiyati, kata "sociometry" berasal dari bahasa Latin "socius," berarti sosial dan "metrum," berarti pengukuran, yang secara harfiah bermakna pengukuran sosial. Oleh karena itu, sosiometri adalah sebuah cara mengukur derajat hubungan antar-orang/manusia. Menurut J.L Moreno, The Sociometry \& the Cultural Order, Soclometry, 6 (1943) dalam Rumiyati A. T., Sosiometri sebagai ilmu pengetahuan berdiri di atas dua kaki, yaitu pada "socius" dan "metrum". Ilmuwan ilmu sosial (sosiologi) terbagi tiga golongan, yaitu: pertama, yang berdiri pada "socius" saja sehingga yang paling penting adalah interindividual/interpersonal saja, mereka menghiraukan pengukuran-pengukuran; kedua, adalah yang beranggapan bahwa yang paling penting adalah pengukuran sosial, masalah fenomena sosial apa yang akan diukur adalah masalah yang kedua; ketiga, adalah yang berdiri di atas kedua-duanya, socius dan metrum.

Menurut Wingkel dan Sri Hastuti dalam Zainuri (2020), sosiometri merupakan suatu metode untuk memperoleh data tentang jaringan hubungan sosial dalam suatu kelompok yang berukuran kecil (10- 50 orang) berdasarkan preferensi antara anggota 
kelompok satu dengan yang lain. sedangkan menurut Ifriadi (2017) yang mengkutip dari Nur Hidayah menyatakan tentang sosiometri yaitu merupakan alat untuk meneliti struktur sosial sekelompok individu dengan dasar penalaan terhadap relasi sosial, status sosial dari masing-masing anggota kelompok yang bersangkutan. Sosiometri dapat juga dikatakan sebagai alat yang digunakan untuk mengumpulkan data tentang dinamika kelompok. Selain itu, sosiometri dapat juga digunakan untuk mengetahui popularitas seseorang dalam kelompoknya serta untuk meneliti kesulitan hubungan seseorang terhadap teman-temannya dalam kelompok, baik dalam kegiatan belajar, bermain, dan kegiatatan-kegiatan kelompok lainnya.

Sosiometri (sociometry) didefinisikan sebagai teknik untuk memetakan relasi daya Tarik dan daya tolak anggota dalam suatu kelompok, Anwar Sutoyo (2012). Sedangkan menurut Gantina Komalasari dkk (2011), sosiometri merupakan metode pengumpulan data tentang pola dan struktur hubungan antar individu-individu dalam suatu kelompok. Dengan demikian, sosiometri merupakan suatu cara untuk mengukur derajat hubungan antar individu/orang/manusia. Sosiometri digunakan sebagai penilaian perilaku seseorang dalam suatu kelompok tertentu. Sosiometri mengukur kualitas hubungan seorang individu dengan individu yang lainnya, kelompok dengan kelompok lainnya, individu dengan kelompok lainya dan begitu sebaliknya.

\section{Pola Hubungan Berdasarkan Penggambaran Sosiogram}

Menurut Anwar Sutoyo (2012), sosiogram merupakan hasil ungkapan relasi antar anggota kelompok. Menurutnya, kemungkinan pola atau bentuk hubungan yang muncul dari sosiogram adalah pola hubungan segitiga (triangle), bintang (stars), jala atau net, dan rantai (chain). Keberagaman pola hubungan yang muncul ini berbanding lurus dengan keberagaman karakteristik individu di dalam suatu kelompok. Berdasarkan yang telah disampaikan Anwar Sutoyo (2012), pola hubungan sosial dibedakan sebagai berikut :

\section{Berbentuk Segitiga (Triangle)}




\section{Berbentuk Bintang (Star)}

Bila pusat (A) tidak ada, maka kelompok akan bubar, karena hubungan kurang menyeluruh.

3. Berbentuk Jala (Net)

Hubungan ini juga mempunyai intensitas cukup kuat. Hubungan cukup menyeluruh, baik, kuat, dan hilangnya seseorang tidak akan membuat kelompoknya bubar.

4. Berbentuk Rantai (Chain)

Hubungan searah atau sepihak tidak menyeluruh, kelompok yang seperti ini keadaanya rapuh.

Gantina Komalasari, dkk (2009) menyampaikan bahwa bentuk hubungan berdasarkan hasil sosiogram, sebagai berikut:

1. Hubungan sosial segitiga menggambarkan intensitas hubungan tiga orang invidu yang cukp kuat atau intim.

2. Hubungan sosial terpusat, menggambarkan tingkat popularitas seorang individu dalam kelompoknya.

3. Hubungan sosial intim, menggambarkan hubungan beberapa orang yang saling memilij satu dengan yang lain dengan intensitas hubungan yang kuat.

4. Hubungan sosial berbentuk jala, menggambarkan pola relasi yang bersifat menyeluruh di mana setiap anggota saling berelasi. Bentuk hubungan ini memiliki intensitas yang kuat, seluruh kelompok sebagai satu kesatuan yang sukar untuk dipisahkan dan ketidakhadiran seseorang dalam kelompok tidak akan menyebabkan perpecahan atau kerapuhan suatu kelompok.

5. Hubungan berbentuk rantai. Menggambarkan pola hubungan searah atau sepihak dan tidak menyeluruh. Intensitas hubungannya rendah, sehingga relasi kelompok mudah rapuh.

Sedangkan menurut Sukardi (2003), dalam sosiogram pada umumnya digunakan beberapa batasan istilah yang dapat menunjukkan posisi individu dalam kelompoknya. Beberapa istilah tersebut sebagai berikut: 
1. Bintang, diberikan kepada mereka yang paling banyak dipilih oleh para anggotanya.

2. Terisolasi, diberikan kepada mereka yang tidak banyak dipilih oleh para anggota dalam kelompok.

3. Klik, diberikan kepada kelompok kecil anggota yang saling memilih satu sama lain dalam kelompoknya.

Dengan demikian, dapat disimpulkan bahwa teori Sukardi menjadi pembatasan yang paling sederhana dalam penggambaran pola hubungan sosial berdasarkan sosiogram. Berkaitan dengan hubungan sosial anak, anak cenderung akan diidolakan, diisolir, atau membentuk geng (kelompok kecil). Maka pola hubungan yang akan terbentuk adalah sebagai berikut :

1. Bintang (Star), merupakan pola hubungan dimana akan ada satu individu dalam suatu kelompok yang cenderung dipilih oleh anggota kelompok yang lainnya. Hal ini kemungkinan individu ini merupakan anak yang pintar, kaya, ganteng/cantik, rajin, dan lain sebagainya.

2. Terisolir, merupakan pola hubungan dimana akan ada satu individu yang cenderung tidak dipilih oleh anggota kelompok yang lainnya. Biasanya individu ini adalah anak yang nakal, bodoh, atau lain sebagainya.

3. Klik (Geng), merupakan pola hubungan dimana individu akan cenderung saling memilih satu sama lain sehingga akan membentuk suatu kelompok kecil dikelas. Hubungan ini biasanya didasarkan atas hobi yang sama, kesenangan yang sama, tetangga, dan lain sebagainya.

\section{KESIMPULAN}

Berdasarkan hasil dan pembahasan, maka dapat disimpulkan bahwa hubungan sosial anak merupakan suatu proses interaksi yang dilakukan oleh anak sebagai usaha menyesuaikan dirinya dengan lingkungan dia hidup untuk dapat mengubah perilaku individu, yang mana dia akan lebih banyak berinteraksi dengan anak seusianya yang lain. dari proses interaksi tersebut maka akan muncul suatu pola hubungan yang 
diukur dengan sosiometri serta digambarkan dalam sosiogram. Pola hubungan yang muncul adalah, 1) bintang (star), merupakan pola hubungan dimana akan ada satu individu dalam suatu kelompok yang cenderung dipilih oleh anggota kelompok yang lainnya. rajin, dan lain sebagainya. 2) terisolir, merupakan pola hubungan dimana akan ada satu individu yang cenderung tidak dipilih oleh anggota kelompok yang lainnya. 3) klik (geng), merupakan pola hubungan dimana individu akan cenderung saling memilih satu sama lain sehingga akan membentuk suatu kelompok kecil dikelas.

\section{DAFTAR PUSTAKA}

Denkin, N. K. 2007. Metodelogi Penelitian Kualitatif Edisi Revisi. Bandung : Remaja. Rosdakarya

http://digilib.uinsby.ac.id/1359/6/Bab\%203.pdf Diakses pada 8 April 2020

Hasanah, N. 2012. Hubungan Sosial Di Kelas Dan Motivasi Belajar Siswakelas X Sekolah Menengah Atas Islam As-Shofa Pekanbaru (Doctoral dissertation, Universitas Islam Negeri Sultan Syarif Kasim Riau).

https://komisiinformasi.go.id/?p=1638 Diakses pada 7 April 2020.

Ifriadi, A. 2017. Pelaksanaan Teknik Sosiometri Oleh Guru Bimbingan dan Konseling di Madrasah Aliyah Negeri 3 Banjarmasin.

Inayah, R. 2013. Pengaruh kompetensi guru, motivasi belajar siswa, dan fasilitas belajar terhadapprestasi belajar mata pelajaran ekonomi pada siswa kelas XI IPS SMA Negeri 1 Lasem Jawa Tengah Tahun Pelajaran 2011/2012. S2 Pendidikan Ekonomi, 2(1).

Jumiyanti, J., Yusmansyah, Y., \& Widiastuti, R. 2015. Hubungan Interaksi Teman Sebaya Dan Motivasi Belajar Dengan Prestasi Belajar Siswa Smp. ABKIN (Jurnal Bimbingan Konseling), 4(3).

Khalilah, E. 2017. Layanan Bimbingan dan Konseling Pribadi Sosial dalam Meningkatkan Keterampilan Hubungan Sosial Siswa. JIGC, 1(1), 41-57. 